\title{
Adıyaman Kazasının Vilayet Olması ve Bu Süreçte Yaşanan Gelişmeler
}

\author{
Mehmet Gündüz ${ }^{1}$ \\ ORCID: 0000-0001-9916-1047
}

Öz

Türkiye'de yapılan idari düzenlemelerle bazı yerleşim yerlerinin idari statüsü değģşebilmektedir. Bu idari düzenlemeler sosyo-ekonomik veya siyasi sebeplerle yapulabilmektedir. Bu yüzden kazaların vilayete dönüş̧ürü̈lmesi beraberinde bazı tartışmaları da getirmektedir. Demokrat Parti Adıyaman kazasının statüsünü değiştirmiştir. Adıyaman kazası 1954 yılında vilayet olmuştur. Bu çalışmayla Adıyaman kazasının vilayet olma süreci ve bu süreçte yaşanan gelişmeler ile halkın beklentileri irdelenmeye çalışılmıştır. Araştırma kapsamında TBMM Zabıtları, dönemin basını ve konuyla ilgili diğer çalışmalardan yararlanılmıştır. Adıyaman'ın il olmastnın sosyo-ekonomik, coğrafi ve siyasi sebepleri bulunmaktadır. Bu sebepler dönemin iktidarı ve muhalefeti arasında tartışmalara yol açmıştır. Besni'nin Adıyaman'a bağlanması bu süreçte yaşanan en önemli meseledir. Besnililerin çoğu Adıyaman yerine Gaziantep'e bağlanmak istemiştir. Ancak yapılan idari düzenleme ile Besni Adıyaman'a bağlanmıştır. Muhalefet Besni'nin siyasi sebeplerle Adıyaman'a bağlandığın iddia etmiştir. İktidar partisi ise bu düzenlemenin siyasi sebeplerle değil sosyo-ekonomik sebeplerle yapıldığın ileri sürmüştür. Adtyaman'ın il olması meselesi dönemin yerel basınında geniş yer bulmuştur. Bu sebeple Adıyaman ilçeden vilayete geçiş sürecinin izlenebileceği en iyi örneklerden biridir.

Anahtar Kelimeler: Adryaman, Malatya, Besni, Kaza, Vilayet.

${ }^{1}$ Dr., İstanbul Erkek Lisesi, E-mail: ekalim02@yahoo.com

idealkent @ C Kent Araştırmaları Dergisi (Journal of Urban Studies)

http://idealkentdergisi.com

Geliş Tarihi Received Date: 18.11.2019 Kabul Tarihi Accepted Date: 31.12.2019 


\title{
Adıyaman District Being a Province and Developments in this Process
}

\author{
* \\ Mehmet Gündüz ${ }^{2}$ \\ ORCID: 0000-0002-4642-4189
}

\begin{abstract}
The administrative status of some settlements can be changed by administrative arrangements in Turkey. These administrative arrangements can be made for socio-economic or political reasons. Therefore, the transformation of districts turn into provinces brings some discussions. The Democratic Party changed the status of Adryaman. Adryaman district became a province in 1954. In this study, the process of becoming a province in Adryaman district and the developments in this process and the expectations of the people were examined. Within the scope of the study, the Grand National Assembly of Turkey Minutes, the press of the period and other related studies were examined. There are socio-economic, geographical and political reasons for Adryaman being a province. These reasons led to controversy between the power and opposition of the period. The inclusion in Besni to Adryaman is the most important issue in this process. Most of the Besni people desired to join to Gaziantep instead of Adryaman. However, Besni joined to Adryaman with the administrative regulation. The opposition claimed that Besni was joined to Adryaman for political reasons. The ruling party argued that this arrangement was made for socio-economic reasons, not for political reasons. The issue of Adryaman becaming a province took place in the local press of the period. Therefore Adryaman is one of the best cases of the transition from the district to the province.
\end{abstract}

Keywords: Adryaman, Malatya, Besni, District, Province.

${ }^{2}$ Dr., İstanbul Boys High School, E-mail: ekalim02@yahoo.com

idealkent @ Kent Araştırmaları Dergisi (Journal of Urban Studies)

http://idealkentdergisi.com

Geliş Tarihi Received Date: 18.11.2019 Kabul Tarihi Accepted Date: 31.12.2019 


\section{Giriş}

Anadolu'nun en eski yerleşim yerlerinden biri olan Adıyaman Hurri, Mitanni, Kummuh, Asur, Pers, Kommagene, Roma, Bizans, Abbasi, Artuklu, Eyyübi, Selçuklu ve Osmanlı gibi birbirinden farklı ve zengin kültürlere ev sahipliği yapmıştır ("İşte Adıyaman", 1971, s.1). Yavuz Sultan Selim döneminde kesin olarak Osmanlı hâkimiyetine giren Hısn-ı Mansur (Adıyaman) 1519 'da Maraş eyaletine sancak olarak bağlanmıştır. 1531'de Elbistan sancağına bağlı bir kaza haline getirilen Hısn-1 Mansur 1563'te yeniden Maraş'a bağlanmıştır. Tanzimat' tan sonra yapılan idari düzenlemelerde 1841'de kaza, 1849 'da Diyarbekir vilayetine bağlı bir sancak durumuna getirilen Hisn-1 Mansur 1859'da Malatya sancağına, 1883'te de Mamüret'ül-aziz vilayetine bağlanmıştır (Hallaçoğlu, 1988, s.377-378).

Cumhuriyet döneminde Malatya'ya bağlı bir ilçe haline getirilen Hısn-1 Mansur'un adı 1926 yılında Adıyaman olarak değiştirilmiştir (T.C. Adıyaman Valiliği, t.y.). Adıyaman il oluncaya kadar yönetim açısından çeşitli değişikliklere uğramıştır. 1928 yılında Adıyaman ilçesine bağlı merkez Adıyaman, Aydınili (Koçali), Çalgan, Samsat, Karıcık ve Kuyucak isimli 6 nahiye bulunmaktaydı. Adıyaman merkez nahiyesine bağlı 40 köy, Aydınili (Koçali) nahiyesine bağlı 26 köy, Çalğan nahiyesine bağlı 48 köy, Samsat nahiyesine bağlı 53 köy, Karıcık nahiyesine bağlı 35 köy ve Kuyucak nahiyesine bağl1 52 köy olmak üzere toplam 254 köy bulunmaktaydı (Dahiliye Vekaleti, 1928). Hükümet 1 Eylül 1930'da Adıyaman ve Kâhta'daki nahiyeleri yeniden düzenlemiştir. Buna göre Adıyaman kazası dâhilinde Akpınar, Tut, Çalğan, Samsat, Kuyucak, Koçali, Kâhta kazası dâhilinde Ahit, Sincik, Tokaris ve Narince nahiye olarak belirlenmiştir. Adıyaman 1954 yılında ise Malatya'dan ayrılarak il olmuştur.

\section{Adıyaman'ın İl Olma Sürecinde Yaşanan Gelişmeler}

Demokrat Parti'nin iktidara gelmesini takip eden yıllarda Adıyaman'ın il olması gündeme gelmiştir. Özellikle 1953 yılından itibaren Adıyaman'ın il olmasıyla ilgili yaşanan tartışmaları yerel basında takip etmek mümkündür. DP'ye muhalif yayınlar yapan Yeşil Adryaman'da çıkan bir haberde Adıyaman kazasına bağlı 19 köyün Kâhta kazasına bağlanması eleştirilmiş ve bu durumun Adıyaman'ı nahiyeye Kâhta'yı ise fiilen vilayete çevireceği ileri sürülmüştür (Adıyaman Bucak mı Oluyor, 1953, s.1). Ancak aynı gazete bu haberden bir süre sonra Adıyaman'ın vilayet olacağını “Adıyamanımız nihayet 
layık olduğu mevkie kavuşacaktır" (Adıyaman Vilayet Oluyor, 1953, s.1) sözleriyle okuyucularına duyurmuştur. Gazete Adıyaman kazasıyla birlikte on kazanının vilayete, dört ilinde kazaya çevrileceğini yazmıştır.

Adıyamanlılar şehirlerinin il olması için çok çaba harcamışlar ve bu amaçla 1953 yılında oluşturdukları bir heyetle Ankara'da temaslarda bulunmuşlardır. Heyetin, Başbakan Adnan Menderes ile ilk teması Ankara'da havaalanında olmuştur. Heyet Başkanı Adıyaman'ın il olması için uzun süre mücadele eden ve burada uzun yıllar öğretmenlik yapan Zeki Adıyaman'dı (TBMM, 1970, s.8). Zeki Adıyaman, Başbakan Menderes'e hitaben "güler yüzünü, açık alnını görmeğe, Adıyaman'ın vilayet emrini almağa geldik" (Başbakan Menderes Heyeti, 1954, s.1) diyerek ilçelerinin il olması talebini kendilerine iletmiştir. Başbakan ise İstanbul dönüşünde konuyu heyetle geniş çaplı görüşeceğine dair söz vermiştir. Yeşil Adryaman bu görüşmenin gerçekleşmediğini ileri sürerek heyetin TBMM Başkanı Refik Koraltan ile görüştügünü̈ yazmıştır. Gazete Koraltan'ın heyete "eğer seçimlerde bütün Adıyamanlılar reylerini DP'ye verirse Halk Partisine tek rey vermezlerse seçimlerden sonra Adıyamanın vilayet olması mukadderdir" dediğini ancak heyette CHP'li vatandaşların olduğunu fark ettiğinde "şaka ediyorum" dediğini ileri sürmüştür (Adıyamanın Vilayet Meselesi, 1954, s.1).

Zeki Adıyaman Cumhurbaşkanı, Başbakan ve birkaç vekille ilçelerinin il olması meselesini konuştuklarını, meselenin ivedi olarak Meclis'e sunulacağı vaadini aldıklarını söylemiş̧ir. Bu konuda siyasilere güvendiklerini belirten Adıyaman, Mart ayı içinde Adıyaman'ın vilâyet olacağını belirtmiştir. Ancak Yeşil Adryaman heyetin adet ve formül haline gelen "dert ve isteklerinizin hepsi de programımızda vardır" cevabını aldığını ileri sürerek verilen cevabı tatminkâr bulmamıştır. Gazete ayrıca bütçe görüşmelerinin yakında başlayacağına dikkat çekerek Adıyaman'ın il olma meselesinin bütçeye tahsisat konmasına bağlı olduğunu ve Adıyaman'ın "Martta vilayet olması bizi de inkisarı hayale uğratır" diyerek Adıyaman'ın vilayet olmasının zor olduğunu ileri sürmüştür (Adıyamanın Vilayet Meselesi, 1954, s.2).

Adıyaman Heyeti 19 Şubat 1954'te Başbakan Adnan Menderes ile bir saat süren bir görüşme gerçekleştirmiş ve Adıyamanlıların isteklerini iletmiştir (Başvekilin Dünkü Kabulü, 1954, s.7). Yeşil Adıyaman 15 Şubat 1954”te “Hayallerden Hakikata" başlığıyla yayınladığı manşet haberinde Adıyaman'ın il olmasıyla şehirlerinin makûs talihini yeneceğini ve dertlerinin sona ereceğini ileri sürmüştür (Hayallerden Hakikata, 1954, s.1,4.). Gazete 22 Şubat 1954 tarihli nüshasında ise "Adıyaman'ın Vilayet Olması Lazımdır" başlığı yayınla- 
dığı manşet haberinde Adıyaman'ın sosyo-ekonomik durumunun kötü olmasından bahisle bir milyon kilo tütün üreten Adıyaman'da neden bir fabrikanın olmadığını ve Adıyaman'ın birçok alanda potansiyelinin yüksek olmasına rağmen neden bunun ortaya çıarılamadığını sormuştur (Adıyaman'ın Vilayet Olması, 1954, s.1). Görüldüğü üzere Adıyaman'ın vilayet olması meselesine Adıyaman yerel basını temkinli yaklaşmışır.

\section{Adıyaman'ın Vilayet Olmasıyla İlgili TBMM'de Yaşananlar ve Adıyaman'ın Vilayet Olmasının Yankıları}

Adıyaman'ın il olması gündeme geldiğinde Malatya'da yayımlanan Sabah gazetesinde "Adıyaman Kazasının Bugünkü Durumu” başlı̆̆ı ile bir yazı yayımlanmıştır. Bu yazıda CHP iktidarının Adıyaman'a üvey evlat nazarıyla baktığı, uzun senelerin ihmal ve alakasızlı̆̆ından dolayı şehrin hiç gelişmediği ileri sürülmüştür. Yazıda yedi mahalle, dört bin küsur bina ve yirmi dört bin nüfusa sahip Adıyaman'ın doğu ve güneydoğu vilayetlerinde eşine rastlanmayacak kadar tabii güzelliğe ve sevimliliğe sahip olduğundan da bahsedilmiştir (Adıyaman Kazasının Bugünkü, 1954, s.1,6). Benzer bir yaklaşımı Yeşil Adryaman gazetesinde de görmek mümkündür. Adıyaman il olmasının dokuzuncu yılı münasebetiyle yayımladığı yazıda coğrafi şartların Adıyaman ve Malatya'yı birbirinden ayırdığını belirten gazete valilerin ihmali yüzünden Malatya'ya kestirmeden bağlanacak bir yolun olmayışının Adıyaman-Malatya münasebetlerini yok derecesine indirdiğini ve Adıyaman'a üvey evlat muamelesi yapıldığını yazmıştır (Vilayet Oluşumuzun Dokuzuncu, 1963, s.1,6).

Demokrat Parti Hükümeti 1954 yılında bazı kazaları vilayet yapmak için harekete geçmiştir. Nitekim Hükümet Malatya vilâyetine bağlı Adıyaman kazasında Adıyaman adıyla yeni bir vilâyet kurulması hakkındaki kanun tasarısını 9 Mart 1954'te Başbakan Adnan Menderes imzasıyla TBMM Başkanlığı'na sunmuştur (TBMM, 1954, s.1). Tasarının gerekçesi ise şöyle açılanmiştır:

Memleketteki demiryolu, liman ve şoselerin çoğalması, hava yollarının geniş mikyasta faaliyete geçmesi, ekonomik gelişme neticesi sınai merkezlerin vücut bulması, zaman mefhumunun hakiki kıymetini almış olması, sosyal ve kültürel yönlerden ileriye doğru mütemadi bir akış görülmesi, köylerimizin kültür alanında geniş bir ufkun açlması ve hulâsa; memleketin her sahasında bir tekevvünün yer alması, bu gelişmeye muvazi olarak idare taksima- 
tımızda zaman zaman değişiklikler ve ilâveler yapılmasını zaruri kılmaktadır... Memleketimizin gelişme alanında kaydettiği ilerlemeler, bazı kaza merkezlerimizde ehemmiyetli tesirler yaparak onun iktisadi durumunu kuvvetlendirmekte ve buna muvazi olarak da kültür ve imar ve diğer sahalarda yeni yeni hamleler kaydedilmektedir. Yukarda kısaca temas ettiğimiz tesirlerle, bölgesinde idari sınırları dışına çıkarak, iktisadi bir sınır çizen ve bu suretle de bulunduğu idari kademenin yapabildiği hizmetler üstünde yeni yeni hizmetler bekleyen bazı kazalarımızın bu durumlarını ele almak ve işi vilâyet konusu içerisinde mütalâa etmek faydalı görülmüştür. Bu maksatla; 15000 nüfuslu Adıyaman Kasabasında ağır ceza mahkemesi, trahom dispanseri, sağlık, sıtma, frengi mücadele teşkilâtı, tütün depoları, tekel müdürlüğü, zirai kooperatif, ortaokulu Ziraat Bankası teşkilâtı olup ticari ve sınai sahasında; üstün bir varlık gösteren ve bu durumu ile de; ileride işgal etmekte olduğu kademenin teşkilât imkânları dışında yeni bir imkâna kavuşmanın zorlayışı ile karşı karşıya bulunan bu kaza da ilişik (1) sayılı cetvelde adları yazılı (4) kaza, (15) nahiye, (292) köyü, (168 498) nüfusu ihtiva etmek üzere tahminen (8 087) km2, yüz ölçüsünde (Adıyaman) adiyle yeniden bir vilâyet kurulması uygun görülmüş ve ilişik kanun lâyihası bu maksatla hazırlanmıştır (TBMM, 1954, s.1-2).

Kanun tasarısında Adıyaman'ın kaza olarak beklenilen hizmetleri yerine getirmekte zorlandığı belirtilerek daha çok iktisadi sebepler üzerinde durulmuştur. Adıyaman kazasında bir vilayette olması lazım gelen çoğu kurumun zaten var olduğunun belirtildiği tasarıda Adıyaman'ın il olmasını zorunlu k1lan gerekçeler ortaya konmuştur. Hükümet tarafından sunulan kanun tasarısı önce Dâhiliye Encümeni tarafından görüşülmüş ve aynen kabul edilmiştir. Tasarı sonra Bütçe Encümeni'ne sevk edilmiş ve burada da kabul edilmiştir (TBMM, 1954, s.7-8). Kanun tasarısı daha sonra TBMM Genel Kurulu'na gelmiştir. Kanun tasarısıyla ilgili bu gelişmelerin yaşandığı günlerde TBMM Başkanı Refik Koraltan 27 Nisan 1954'te Adıyaman'da yaptığı mitingde Ad1yaman'ın yakında il olacağı müjdesini vermiş̧tir (BMM Reisi, 1954, s.1). Ad1yaman'ın il olması için TBMM'ye kanun teklifinin sunulması şehirde büyük sevince vesile olmuştur. Yeşil Adıyaman bu sevinci şöyle betimlemiştir:

Koskoca kasaba halkı, birkaç günden beri bayram yapıyor. Hepsi pür neşe birbirlerinin ellerini sıkıyorlar. Kurtuluş bayramlarını, dini bayramlarını tesit ediyorlar sanki Hakları da yok değil. Zira metruk bir halde bulunan Yeşil Adıyaman arazisinin feyzleneceğini, monoton ve mevtai bir hayat yaşayan insanlarının yakın bir atide canlanacağını ve üstün bir hayat seviyesine erişeceğini müjdeleyen haberler alınmıştır. ("Güzel Kazamızın...", 1954, s.1) 
Adıyaman ilçesinin il olacağı haberi Adıyamanlıların beklentilerini de artmıştır. Adıyamanlılar kazalarının vilayet olmasından büyük memnuniyet duyarken Adıyaman'a bağlanması düşünülen Besni kazasında çoğu vatandaş Adıyaman'ın il olması için verilen kanun teklifine karşı çıkmıştır. Hatta 4 Haziran 1954'te Besni'ye kardeşiyle bayramlaşmak için giden Zabıta Memuru Abdurrahman Akgün'ü bazı Besnililer tartaklanmış ve aracına zarar vermiştir. Yeşil Adıyaman bu olayı sütunlarına taşıyarak "Biz Adıyamanlılara, bu durum karşısında efendiliğimizi muhafaza etmek, elimizden geldiği kadarıyla Besnililere hürmet etmek düşer" diyerek Adıyaman'ın il olmasının Besnililer için de faydalı olacağını yazmıştır (Kazamızın Vilayet, 1954, s.1). Besnililer ise nüfusu kendileri kadar olan bir yere bağlanmak istemediklerini belirterek Malatya veya Gaziantep'e bağlanma isteklerini dile getirmiştir. Sabah gazetesinin haberine göre yaklaşık on bin kişilik bir grup 6 Haziran 1954'te PTT binasına giderek Besni'nin Adıyaman'a bağlanması kararı tasvip etmediklerini belirtmiştir. Ayrıca Besni Kaymakamı ve Besni parti başkanları da Malatya'ya giderek konuyla ilgili temaslarda bulunmuştur (Besnililer Kazalarının, 1954, s.1). Ancak Besni'nin bu dönemdeki nüfusu göz önüne alındığında bu rakamın oldukça abartılı olduğu söylenebilir.

Kanun tasarısı ile Dâhiliye ve Bütçe Encümenlerinin mazbataları 14 Haziran 1954'te Meclis Genel Kurulu'nda görüşülmüştür (TBMM, 1954, s.164165). Görüşmelerde ilk sözü Hükümet adına İçişleri Bakanı Namık Gedik almıştır. Namık Gedik Türkiye'nin idari taksimatından bahsettikten sonra genel nüfusun \%74,8'ini oluşturan köy halkına genel hizmetleri mümkün olduğunca yakına götürmenin öneminden ve bunu sağlamak için 1950 senesinden beri 71 nahiye ve 62 kazanın teşkil olunduğundan bahsetmiştir. Gedik, coğrafi durum, iktisadi ilişkiler göz önünde bulundurulması şartıyla vilayetlerin genel ve yerel hizmetlerin rasyonel bir şekilde yerine getirebilmesi için vilayet idare sisteminin günün koşullarına göre yeniden düzenlenmesinin gerekliliği üzerinde durmuştur. Gedik batıdan doğuya uzanan yüksek dă̆larla birbirinden ayrıldığından dolayı Adıyaman ile Malatya arasında iktisadi münasebetlerin bulunmadığını söylemiştir. Gedik özellikle kış mevsiminde Malatya ile bağlantısı kesilen "Adıyaman, Kâhta, Gerger ve Besni kazalarının Malatya'dan ayrılarak ayrı bir vilayet haline getirilmesi, bu mıntıka halkının maruz bulundukları müşkül durumu ıslah ve sözü geçen bölgenin iktisadi inkişafını sağlamak bakımından zaruri" olduğunu sözlerini eklemiştir (TBMM, 1954, s.164-165).

İçişleri Bakanı'ndan sonra İçel Milletvekili Hüseyin Fırat söz almıştır. Adıyaman'ın il olmasının çok büyük bir zaruret olduğunu belirten Fırat, Bakanın 
söylediği gerekçeleri biraz daha detaylandırarak "Adıyaman, Besni ve Kâhta ovaları 4,5 milyon dönüm genişliğinde tarihî Mezopotamya ovasının başlangıcl, madenleriyle, tarihî eserleriyle meşhur ve son yapılan tetkiklerde çok zengin petrol membalarının bulunduğu sabit olan geniş bir" ova olduğunu söylemiş ve Adıyaman il olması kararını desteklemiştir (TBMM, 1954, s.165). Malatya Milletvekili Nüvit Yetkin ise meseleye dar bir bölgecilik zihniyetiyle değil, memleketin inkişafı bakımından ve prensipler zaviyesinden mütalâa ettiğini ve Hükümetin getirdiği bu lâyihayı desteklediğini belirtmiştir. Yetkin Adıyaman kazasının öteden beri hızlı bir gelişim gösterdiğini ve coğrafi durumu itibariyle de Malatya'dan ayrı hususiyetleri olduğunu, ziraat bakımından, iktisat bakımından daha ziyade güney iklimine ve şartlarına bağlı kaldığını söylemiştir. Yetkin ayrıca Adıyaman' da birçok kurumun zaten var olduğunu belirterek Adıyaman'ın vilayet olmasını kararını desteklemiştir (TBMM, 1954, s.166-167). Nüvit Yetkin Adıyaman'ın il olmasını desteklemekle birlikte nüfusu ve nahiye sayısı Adıyaman'dan daha fazla olan Besni'nin Adıyaman'a bağlanmasına karşı çıkmıştır. Yetkin Besni kazasının "coğrafi, zirai ve iktisadi şartlar itibariyle de Adıyaman'la ilgi tesisine imkân vermeyen, dolayısıyla Gaziantep'e iktisaden bağlı olan bir bölge" olduğunu ileri sürerek "bu itibarla Malatya'dan ayrılması coğrafi bakımdan zaruri ise Gaziantep'e bağlanmasının" daha uygun olacağını söylemiştir. Ayrıca Besni ile Adıyaman arasında öteden beri rekabet olduğunu belirterek "Malatya'nın 1950'den beri seçimlerde Halk Partisine temayülünden bu ilin tecziye edildiği ve son 1954 seçimlerinde de iktidar partisine aynı temayülü gösterdiği için Adıyaman Kazasının bilâkis mükâfatlandırıldığı yolunda matbuata akseden bazı dedikodular" olduğunu iddia etmiştir (TBMM, 1954, s.167).

Adıyaman'ın il olmasını destekleyen Malatya Milletvekili Hilmi Özbay ise “Besni'nin Adıyaman'a bağlanmasını kabul etmiyorum ve bu hususlara yakından vâkıf bir arkadaşınız sıfatıyla Besni'nin hayatiyetini muhafaza ve onun iktisadiyatını ve refahını yükseltecek hususları göstermek suretiyle Besni'nin Adıyaman'a değil, Gaziantep'e bağlanmasını teklif ediyorum" diyerek Besni'nin Adıyaman'a bağlanmasına karşı çıkmıştır. Besni'nin hissen Gaziantep'e bağlı olduğunu belirten Özbay "eğer Adıyaman vilâyet olur ve Besni bu vilâyete bağlanacak olursa" Besni' de amansız bir göç başlayacağını ve ahalisinin Antep'e göç edeceğini ileri sürmüştür (TBMM, 1954, s.167-168). Seyhan Milletvekili Sinan Tekelioğlu'da benzer sebeplerle Besni'nin Antep'e bağlanmasına karşı çıkmıştır (TBMM, 1954, s.168). Bakandan sonra söz alan ve daha önce Besni'de iki sene kaymakamlık yapan Kars Milletvekili Mehmet Hazer'de Adıyaman'ın il olmasını desteklemiş 
ama Besni'nin Adıyaman'a bağlanmasına karşı çıkmıştır. Hazer "bugün Besni'liler, vilâyet olması halinde de yine Adıyamana gitmeyeceklerdir" demiştir (TBMM, 1954, s.169-170).

Dâhiliye Encümeni Reisi Rükneddin Nasuhioğlu “teşkilâtı mülkiyeyi kurarken, değiştirirken, idari hizmetlerin mümkün olduğu kadar halka yakın olması prensibini takip ediyoruz... İktisadi vaziyetinin Antep'le olması meselesi, yine Antep'le olan iktisadi ve ticari münasebatın tadil etmez" diyerek Besni'nin Gaziantep'e bağlanması tekliflerine karşı çıkmıştır (TBMM, 1954, s.169-170). Gaziantep Milletvekili Süleyman Kuranel ise yeni yapılan yollarla Antep ile Besni arasındaki mesafenin kısaldığını belirterek daha önce Antep'e bağll iken 1933'te Malatya'ya bağlanan Besni'nin "gerek iktisadi vaziyeti, gerek zirai vaziyeti ve gerekse içtimai durumu Gaziantep'le" ilgili olduğunu söylemiş ve Besni'nin Adıyaman'a bağlanması durumunda yakın bir gelecekte bu durumun yeniden gözden geçirilmek zorunda kalınacağını belirterek Besni'nin Antep'e bağlanması gerektiğini ileri sürmüştür (TBMM, 1954, s.171). İçişleri Bakanı Namık Gedik bir vilâyetin bünyesini yeniden kurarken onu teşkil eden kazaların vilâyet merkezine olan mesafesi, coğrafi, iktisadi şartları birinci derecede dikkate alındığını ve kazaların bir vilâyete bağlanmasında başka vilâyetlere olan mesafeyle ele alınan vilâyete olan mesafesinin göz önünde tutulduğunu belirtmiştir. Besni'nin Gaziantep'e olan mesafesi 154-156 kilometre, Adiyaman merkezine ise 54 kilometre olduğunu belirten Gedik Besni köylerinin ise Adıyaman'a daha yakın olduğunu söylemiştir. "Besni, iktisaden ve coğrafi bakımdan verdiğim rakamlara göre Adıyaman'ın bünyesi içindedir" (TBMM, 1954, s.168-169) diyen Namık Gedik 300 bin dekar genişliğinde bulunan büyük Adıyaman ovası da zirai karakter itibariyle bir vahdet manzarası arz ettiğini, Besni'nin Adıyaman'ın bilhassa ziraat bakımından Adıyaman'ın bir parçası olduğunu söylemiştir. Gedik “Besni ile Adıyaman arasında öteden beri mevcut olan ve tamamen hisse istinad etmekte olan birtakım rekabetlere Hükümet tatbikat yaparken mahkûm olamaz, buna imkân yoktur" diyerek Hükümetin yaklaşımını ortaya koymuştur (TBMM, 1954, s.168-169).

Gedik ayrıca Adıyaman'ın vilâyet olmasından sonra Besni'nin Gaziantep pazarından istifade etmesi için önünde bir mâni olmadığını söylemiştir (TBMM 1954, s.172). İçel Milletvekili Hüseyin Fırat ise “Besni'nin 65 bin nüfusu Adıyaman'ın vilâyet olması ile muhterem arkadaşlarım büyük bir bayram havası içindedir. Yalnız Besni'nin içerisinde bulunan 20-25 fıstık tüccarı Hükümetin almakta bulunduğu bu karar aleyhindedir" iddiasında bulunmuştur (TBMMZC, 1954, s.172). Gaziantep Milletvekili İhsan Dai ise iktisadi 
ve Antep'e uzak olsa bile Antep'in Besni'ye kadar uzanan toprakları üzerinde bir kazanın olmaması gibi sebepleri öne sürerek Besni'nin Antep'e bağlanmasının gerekliliğini savunmuştur (TBMM, 1954, s.172-174).

TBMM'de yaşanan tartışmalara bakıldığında Malatya milletvekilleri dâhil konuşma yapan tüm vekillerin Adıyaman'ın il olmasını desteklediği görülmektedir. Yaşanan tartışmanın kilit noktasını Besni kazasının Adıyaman'a bağlanıp bağlanmaması meselesi oluşturmuştur. Başta Malatya ve Gaziantep milletvekilleri olmak üzere bazı vekiller Besni'nin Adıyaman'a değil Gaziantep'e bağlanması gerektiğini savunmuştur (TBMMZC, 1954, s.186-189). Her ne kadar Besni mesafe olarak Adıyaman'a daha yakın Gaziantep'e daha uzak olsa da konuşmacıların çoğu ekonomik sebepler ve Besnililerin Gaziantep'e bağlanmakta yana olduğu savlarını ortaya koyarak buranın Adıyaman'a değil Gaziantep'e bağlanması gerektiğini savunmuştur. Hükümet kanadı ise Besni'nin Adıyaman'a bağlanmasının daha doğru olduğu ve iktisadi olarak Besni ile Gaziantep arasındaki ilişkinin sürmesinin önünde bir engel olmad1ğını savunmuştur. Bazı araştırmacılara göre Adıyaman'ın il olmasında daha çok siyasi sebepler etkili olmuştur. Gazeteci Naif Karabatak Adıyaman'ın il olmasını şöyle açıklamıştır:

İl merkezi olan Malatya'yla ilçe olan Adıyaman arasında çok uzun bir mesafe vardı. İşler zamanında yapılmıyor, vatandaş mağdur ediliyor, ilçe merkezine hizmet yeterli ve zamanında gelmiyordu... Bu değişim, her ne kadar bir ihtiyaçtan dolayı olsa da, aslında siyasi hesap nedeniyledir. Bu hesabın esası, CHP Genel Başkanı İsmet İnönü'nün Malatyalı olmasından dolayıdır. İnönü Malatyalı olunca, oylar da haliyle CHP'ye gidiyordu, Adıyamanlıların Demokrat Partiye verdiği oy vekil çıkartmıyordu. Adıyaman vilayet olunca, Adıyaman'ın oyu Demokrat Partiye, yani merhum Adnan Menderes'e gitti. Dolayısıyla Adıyaman'ın Malatya'dan ayrılmasının altında yatan espri, siyasi hesap esprisidir. (Karabatak, 2017).

TBMM'ye sunulan kanun tasarısında kurulacak Adıyaman ilinin Adıyaman, Besni, Kâhta ve Gerger kazalarından oluşması öngörülmüştür. Ancak kanun tasarısı Meclis Genel Kurulu'nda tartışılırken Çelikhan'ında Adıyaman'a bağlanması için bir önerge verilmiş ve bu önerge kabul edilmiştir (TBMM, 1954, s.175). 14 Haziran 1954 tarihli ve 6418 sayılı kanun ile Malatya vilâyetine bağlı Adıyaman kazası kaldırılarak merkezi Adıyaman olmak ve yine Malatya vilâyetine bağlı Besni ve Kâhta kazaları ile yeni kurulmuş olan Gerger ve Çelikhan kazalarını ihtiva etmek üzere Adıyaman adıyla yeni bir vilâyet kurulmuş ve eski Adıyaman kazasını ihtiva eden nahiye ve köyler Adıyaman vilâyetinin merkez kazasına bağlanmıştır (Resmi Gazete, 1954, 
s.9681). Adıyaman ile aynı gün Sakarya'da il olmuştur (Adapazarı ve Adıyaman, 1954). Malatya vilâyetine bağlı Adıyaman kazasında Adıyaman adıyla yeniden bir vilâyet kurulması hakkındaki kanun oylamasına 536 milletvekilinden 298'i katılmıştır. Oylamaya katılan tüm vekiller evet oyu kullanmıştır. Adıyaman'ın il olmasını desteklemelerine rağmen Malatya vekillerinden hiçbiri oylamaya katılmamıştır. Gaziantep vekillerinden beşi oylamaya katılırken üçü oylamaya katılmamıştır (TBMM, 1954, s.186-189).

Adıyaman ili için verilen kanun tasarısında Adıyaman kazasının 1 Ocak 1955 tarihinden itibaren il olması planlanmıştır. Ancak Kocaeli Milletvekili Turan Güneş İdare-i Umumiye-i Vilâyat Kanununun 11. maddesine göre vilâyet umumi meclislerinin Aralık ayının ilk haftasında toplantılarını yaptıklarını ve eğer kanunun yürürlüğe girme tarihi 1 Ocak'a bırakılırsa Malatya ile Adıyaman vilâyetlerinin il meclislerinin bir arada toplanacaklarını ve bu durumun karışıklıklara yol açacağını belirtmiştir. Güneş kanunun yürürlüğe giriş tarihinin 1 Ocak 1955 değil 1 Aralık 1954 olmasını teklif etmiştir. Teklif kabul edilmiştir (TBMM, 1954, s.178-179).

Yeni Sabah gazetesinde "İki Yeni Vilayet" başlığı ile yayımlanan yazıda Adıyaman ile Sakarya'nın il olmasını uğurlu gün olarak değerlendirilmiştir. Fakat gazete Kırşehir'in ilçe yapılmasının bütün yurdun kalbinde az çok üzüntüye sebep olduğunu ve her ne kadar resmi yetkililer reddetse de burasının ilçe yapılmasında 2 Mayıs 1954 seçimlerinde Kırşehirlilerin Cumhuriyetçi Millet Partisi adaylarına oy vermesinin etkili olduğuna kimsenin şüphesinin olmadığını ileri sürmüştür (İki Yeni Vilayet, 1954, s.1). Hikmet Sami Türk de 1950'li yıllarda muhalif partilere oy veren bazı il ve ilçelerin cezalandırıldığını ileri sürerek Malatya'nın Malatya-Adıyaman olarak ikiye bölünmesini bir parti ya da adayın siyasi avantaj elde edeceği şekilde seçim bölgesi sınırlarını değiştirilmesi olarak tanımlanabilecek Gerrymandering'e örnek olarak göstermiştir (Avaner, 2009, s.48). Nitekim genel seçim sonuçları kısmen bu yaklaşımı desteklemektedir.

1954 seçimlerinde DP Malatya'da oyların \%44,5'ni almasına rağmen milletvekili çıkaramamıştır. CHP ise oyların \%54,3'nü alarak milletvekillerinin 12'sini yani tamamını çıkarmıştır. 1957 seçiminde ise CHP Malatya'da oyların 65,3'ü alarak 9 milletvekilinin tamamını çıarırken, DP Adıyaman'da oyların \%49,8'ini alarak 5 milletvekilinin tamamını çıkarmıştır. Dolaysıyla Demokrat Parti kendisi için faydalı bir hamle yaparak Adıyaman'ı il yapmış ve buradan 5 vekil çıarmayı başarmıştır. Yeşil Adıyaman Demokrat Parti'nin iktidardan düşmesinden sonra şu yorumu yapmıştır: 
Tablo 1. 1954 ve 1957 Genel Seçim Sonuçları ile Adıyaman ve Malatya' daki Seçim Sonuçları

\begin{tabular}{|c|c|c|c|c|c|c|c|}
\hline & \multicolumn{2}{|c|}{ Malatya } & \multicolumn{2}{|c|}{ Adiyaman } & \multicolumn{2}{|c|}{ Genel Sonuçlar } \\
\hline & & $\begin{array}{l}1954 \\
\text { Seçimi }\end{array}$ & $\begin{array}{l}1957 \\
\text { Seçimi }\end{array}$ & $\begin{array}{l}1954 \\
\text { Seçimi }\end{array}$ & $\begin{array}{l}1957 \\
\text { Seçimi }\end{array}$ & 1954 Seçimi & 1957 Seçimi \\
\hline \multicolumn{2}{|c|}{$\begin{array}{l}\text { Kayıtlı seçmen } \\
\text { sayısı }\end{array}$} & 227.529 & 160.416 & - & 92.851 & 10.262 .063 & 12.078 .623 \\
\hline \multicolumn{2}{|c|}{$\begin{array}{l}\text { Oy kullanan } \\
\text { seçmen sayısı }\end{array}$} & 210.778 & 120.295 & - & 60.923 & 9.095 .367 & 9.153 .949 \\
\hline \multicolumn{2}{|c|}{ Katılım oranı $(\%)$} & 92,6 & 75 & - & 82,1 & 88,6 & 75,8 \\
\hline \multicolumn{2}{|c|}{ Milletvekili sayısı } & 12 & 9 & - & 5 & 541 & 602 \\
\hline \multirow[t]{3}{*}{$\mathrm{CHP}$} & $\begin{array}{l}\text { Alınan oy } \\
\text { sayısı }\end{array}$ & 88.235 & 39.229 & - & 28.684 & 3.162 .196 & 3.753 .136 \\
\hline & Oy oran 1 & 44,5 & 32,8 & - & 37,7 & 34,8 & 41 \\
\hline & MV sayısı & 0 & 0 & - & 0 & 31 & 178 \\
\hline \multirow[t]{3}{*}{$\mathrm{DP}$} & $\begin{array}{l}\text { Alınan oy } \\
\text { sayısı }\end{array}$ & 557 & 847 & - & 37.868 & 5.151 .550 & 4.372 .621 \\
\hline & Oy oranı & 0,1 & 0,7 & - & 49,8 & 56,6 & 47,8 \\
\hline & MV sayısı & 0 & 0 & - & 5 & 503 & 424 \\
\hline \multirow[t]{3}{*}{$\mathrm{CMP}$} & $\begin{array}{l}\text { Alınan oy } \\
\text { sayısı }\end{array}$ & - & 1.483 & - & 253 & 434.085 & 651.603 \\
\hline & Oy oranı & - & 1,2 & - & 0,3 & 4,8 & 7,1 \\
\hline & MV sayısı & - & 0 & - & 0 & 5 & 4 \\
\hline \multirow[t]{3}{*}{$\mathrm{HP}$} & $\begin{array}{l}\text { Alınan oy } \\
\text { sayısı }\end{array}$ & 88.235 & 39.229 & - & 9.236 & - & 355.701 \\
\hline & Oy oranı & 44,5 & 32,8 & - & 12,2 & - & 3,9 \\
\hline & MV sayısı & 0 & 0 & - & 0 & - & 4 \\
\hline
\end{tabular}

(TüİK, t.y.)

1950 yılında, çok partili sistemin sonucu olarak iktidar değiştikten sonra da tatbikat göstermiştir ki mevcut şartlar içinde Adıyaman'ın Malatya'ya bağlı bir ilçe olarak kalmasına imkân yoktur. Bu arada Adıyamanlılar olarak istisnasız büyün halkın temayülü Malatya'dan ayrılmaktı. Bu temayülün bir sonucu olarak zıddı yönde bir oy kullanılmıştı. Yıl 1954 Adıyaman'ın siyasi durumu anlaşılmış, İktidar partisinin en güvendiği bir seçim bölgesi olduğu ortaya çımıştı. Fakat gerek Malatya merkezi ve gerekse diğer ilçelerin oy çoğunluğu arasında Adıyaman'ın oyları nazım bir rol oynamaktan geri kalıyordu. Devrik iktidar daha ziyade bu noktayı dikkate alarak kendi partisinin oylarını kurtarmak için Adıyaman'ı ayırıp müstakil bir il haline getirmeyi düşündü; böylece hem Adıyamanlıların arzusunu ifa edecek hem de kendi amalini tahakkuk ettirmiş olacaktı... Devrik iktidar Adıyaman'ı siyasi maksatlarla il haline getirmek istemiş, fakat farkında olmadan isabetli bir iş yapmıştı. Zira il halice gelmek Adıyaman'ın her bakımdan aksine tek kelime söylenmeyecek derecede haklı idi. Böyle olduğu için de, Adıyaman il haline getirilişini hiç kimseye borçlu değildir. (Vilayet Oluşumuzun Dokuzuncu, 1963, s.1,6). 
İsmail Safi ve Talip Kurşuncu Adıyaman'ın Malatya'dan koparılarak il yapılmasının iyi niyetli bir idari ve mülki taksimat girişimi olmadığı ve bu uygulamanın Malatya'nın cezalandırmasına yönelik bir girişim olduğunu iddia etmiştir. Bu araştırmacılara göre Türkiye genelinde il olmayı bekleyen ve kanun layihasındaki şartları fazlasıyla taşıyan birçok ilçe olduğu halde Adıyaman, Nevşehir ve Sakarya'nın tercih edilmesinde DP'nin kendisine oy vermeyen bölgeleri cezalandırması ve oy veren bölgeleri ödüllendirmesi etkili olmuştur. Aynı araştırmacılar Besni'nin Adıyaman'dan her anlamda üstün olmasına rağmen Adıyaman'ın il olarak tercih edilmesinde Besni'nin genel seçimlerde $\mathrm{CHP}^{\prime}$ yi Adıyaman'ın ise $\mathrm{DP}^{\prime}$ yi desteklemesinin etkili olduğunu ileri sürmüştür. Araştırmacılar iki ilçe arasında il olabilmek için yıllardır süren bir rekabet olduğunu, Adıyaman'ın tercih edilmesinin bir siyasi tercih ve Besni'yi cezalandırmaya yönelik olduğunu iddia etmiştir (Safi-Kurşuncu, 2019, s.63-64). Ancak bu yaklaşımın tamamen doğru olduğunu söylemek zordur. Çünkü Adıyaman'ın il olması için kanun teklifi 2 Mayıs 1954 genel seçimlerinden yaklaşık iki ay önce verilmiştir. Ayrıca Adıyaman il olduğunda şehir merkezi nüfusu Besni'nin şehir merkezi nüfusundan fazlaydı. Adıyaman'ın toplam nüfusu Besni'nin altında olmakla birlikte Adıyaman'ın köy sayısı Besni'den fazlaydı.

Tablo 2. Adıyaman ve Besni'nin 1940-1955 Yılları Arasındaki Nüfusu ve Köy Sayısı

\begin{tabular}{|c|c|c|c|c|c|c|c|c|c|c|c|c|c|}
\hline & \multicolumn{4}{|c|}{ Şehir Nüfusu } & \multicolumn{4}{|c|}{ Köy Nüfusu } & \multicolumn{4}{|c|}{ Toplam Nüfus } & \multirow{2}{*}{$\begin{array}{l}\text { Köy } \\
\text { Sa- } \\
\text { yisı }\end{array}$} \\
\hline & 1940 & 1945 & 1950 & 1955 & 1940 & 1945 & 1950 & 1955 & 1940 & 1945 & 1950 & 1955 & \\
\hline 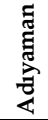 & 11522 & 1092 & 11633 & 13966 & 40010 & 37430 & 43685 & 46995 & 51532 & 47622 & 55318 & 60961 & 105 \\
\hline $\begin{array}{l}\vec{D} \\
\text { Dू }\end{array}$ & 8826 & 9134 & 10500 & 11960 & 40058 & 42815 & 47866 & 55476 & 48884 & 51969 & 58366 & 67436 & 85 \\
\hline
\end{tabular}

(T.C. Başbakanlık IGM, 1961)

Adıyaman'ın kurulduğu yerin şehirleşmeye ve genişlemeye daha uygun olduğu görülmektedir. Ayrıca Adıyaman konumu itibarıla diğer ilçelere Besni'ye göre daha merkezi bir konumda yer almaktadır. Bütün bu durumlar göz önüne alındığında Adıyaman'ın il merkezi olarak tercih edilmesinde sadece siyasi sebeplerin etkili olmadığı anlaşılmaktadır. 




Harita 1. Adıyaman ve Çevresinin Arazi Haritası. (Googlemaps)

\section{Adıyaman Kazasında Vilayete Geçiş İçin Yapılan Hazırlıklar}

Adıyaman'ın il olması hakkındaki kanunun çıkmasının üzerinden üç ay geçmiş olmasına rağmen hazırlıkların çok yavaş ilerlediği belirten Yeşil Adıyaman her şeyi hükümet ve devletten beklemenin abes olduğunu söyleyerek “VILÂYYET ADIYAMAN! Güzel bir sifat. Bunu ne zannediyoruz? Eğer biz, birkaç fazla memurun, bir şehrin her bakımdan gelişmesine âmil olacağını zannediyorsak çok aldanıyoruz" diyerek yapılan hazırlıkların yetersizliğine değinmiştir. Aynı gazete konuşmaktan çok iş yapmanın önemi üzerinde durarak "Hükümet, Adıyaman'ı vilâyet yaptı; fakat inkişafını yine bizlere b1raktı" ifadesiyle yapılan hazırlıklara herkesin destek vermesinin gerekliliği üzerinde durmuştur (Vazife Bizi Bekliyor, 1954, s.1-2).

Gazete daha sonraki sayılarında da benzer uyarılarda bulunarak hazırlıkların çok eksik olduğunu belirtmiş ve 15-20 zenginin elbirliği yapması halinde gelecek memurlar için 30-40 evin yapabileceğini yazmıştır (Gene Aynı Dert, 1954, s.1). 23 Ekim 1954 tarihinde ise vilayet teşkilâtının faaliyete geçebilmeni için yer temin ve tespiti maksadıyla Malatya Valisi Ahmet Tekelioğlu'nun refakatinde Mahalli İdareler Umum Müdürü Cemil Keleşoğlu, Vilâyetler İdaresi Umum Müdürü Fethi Tanksu ve Vilâyetler İdaresi Umum Müdür Muavini Sabri Özdil'den oluşan bir heyet Adıyaman'a gelmiş ve incelemelerde bulunmuştur (Adıyamanın Vilayet Teşkilatı, 1954). A. Kılıç 18 
Kasım 1954'te "Kutsal Günümüz" başlığıyla kaleme aldığı yazısında Adıyaman'ın il olacağı 1 Aralık 1954 Çarşamba gününün her Adıyamanlının kalbine ve kafasına nakşedildiğini belirterek "Nasıl ki her millet, kendi dini ve milli bayramlarını sabırsızlıkla beklerse, biz de bu günü sonsuz bir şevkle beklemekteyiz... O günün, o kutsal günün şerefine bu güne kadar eşine ender rastlanan parlak bir merasim yapılması hususunda bütün Adıyamanlılar adeta biri birleriyle yarış yapmaktadır" demiştir (Kılıç, 1954, s.1).

Adıyaman il yapan kanun yürürlüğe girmeden önce Belediye Meclisi yeni Belediye Başkanı'nı seçmiştir. Belediye Meclisi Develi Hâkimi Adıyamanlı Fuat Bilgin'i Belediye Başkanı olarak seçmiştir (Yeni Belediye Reisimiz, 1954, s.1). Adıyaman Valiliğine ise daha önce Adıyaman kazasında kaymakamlık yapan İbrahim Tevfik Kutlar atanmıştır (Vilayetimiz Kuruluş Merasiminde, 1954, s.1; Umumi Meclis Toplantısı, 1954, s.1). Adıyaman'ın il olacağı 1 Aralık 1954 tarihi için Adıyamanlılar önemli hazırlıklar yapmışlardır. Gelecek misafirlerle meşgul olup her türlü ihtiyaçlarını temin etmek ve merasimin düzenli olmasını sağlamak için "Vilâyet Kutlama Komitesi" adıyla bir komisyon kurulmuştur. Ayrıca her Adıyamanlı üzerine düşen vazifenin önemini bildiğinden canla başla çalışmıştır. Esnaf ise kurbanlık hayvanlar temin etmiştir (Vilayet Kuruluş Merasimi, 1954, s.1). Adıyaman'ın il olması münasebetiyle yapılacak törene TBMM Başkanı Refik Koraltan, İçişleri Bakanı Namık Gedik, milletvekilleri, Emniyet Genel Müdürü ve Jandarma Genel Komutanı'nın katılması öngörülmüştür (Adıyamanın Vilayet Olması, 1954, s.1; Adıyaman Vilayeti, 1954, s.1; Adıyaman, Adapazarı, 1954, s.7). Bu amaçla Ankara'dan uçakla Malatya'ya gelen heyet 1 Aralık 1954 günü sabahı Adıyaman'a hareket etmiştir (Adıyaman Merasimle, 1954, s.1). Adıyaman Valisi, Belediye Başkanı, parti il başkanları, esnaf birliklerinden oluşan Adıyaman Heyeti misafirleri Gölbaşı civarında karşılamıştır (Adıyaman ve Sakarya'da, 1954, s.1,7). Bu arada Gölbaşılılar Besni'ye bağlı kasabalarının da kaza olmasını istemek için gazetelere mektuplar göndererek Meclis Başkanı Refik Koraltan'ın dikkatini çekmek istemişlerdir (Adıyaman Merasimle, 1954).

TBMM Başkanı Refik Koraltan, İçişleri Bakanı Namık Gedik, milletvekilleri ve diğer devlet görevlilerin yer aldığı heyeti halk yol güzergâhı üzerinde büyük bir coşkuyla karşılamıştır (Adıyaman, Tam Bir, 1954, s.1). Adıyaman 1 Aralık 1954'te TBMM Başkanı Refik Koraltan, İçişleri Bakanı Namık Gedik, milletvekilleri, devlet görevlileri ve kalabalık bir halk kitlesinin katıldığı törenle il olmuştur. Tören saat 13.30' da başlamıştır (Adıyaman ve Sakarya Dün, 1954, s.1,7). Civar köylerden, kazalardan ve komşu illerden gelen yaklaşık kırk bin kişilik vatandaş törenlere katılmak üzere Adıyaman'a gelmiş, sokak 
ve caddeleri hıncahınç doldurmuştur (Adiyaman Merasimle, 1954, s.1). Törende ilk olarak Adıyaman'ın il olmasında büyük emeği olan Öğretmen Zeki Adıyaman bir konuşma yapmıştır. Daha sonra sırasıyla Genç Demokratlar Teşkilatı Başkanı Abdurrahman Şeref Bilgiç, İçel Mebusu Hüseyin Fırat, İçişleri Bakanı Namık Gedik ve Meclis Başkanı Refik Koraltan konuşmuştur (Adıyaman ve Sakarya Dün, 1954, s.1). İçel Mebusu Hüseyin Fırat yaptığı konuşmada günün manasını anlatarak Adıyamanlıların yıllardan beri hasretle bekledikleri büyük bir emelin gerçekleştiğini belirtmiştir. Hükümet adına konuşan İçişleri Bakanı Namık Gedik sözlerine sevgili Adıyamanlı hemşehrilerim diye başlamış, Adıyamanlıların bayramını hükümet adına kutlamış ve Başbakan Adnan Menderes'in tebriklerini iletmiştir. Gedik sözlerine şöyle devam etmiştir:

Bugünden itibaren Türkiye Cumhuriyeti yeni teşkilât haritasına iki tane genç vilâyet adı eklendi. Adıyaman ve Sakarya. Altmışaltı vilâyet... Bu vatanın üstündeki gökler bizim, bu vatanın üzerinde dolaştığımız toprak bizim. Denizler bizim... Mademki bu aziz topraklar üstünde yaşayan böyle bir büyük ve asil millet var, mademki bu topraklar dünyalar yaşadıkça bizim olacaktır, o halde biz millet olarak bugünden yarma daha mesut ve daha bahtiyar olacağız. Sizin gönlünüzden doğan hükümetiniz ve millî iradeyi katıksız olarak kendi bünyesinde temsil etmekte bulunan Büyük Millet Meclisiniz böyle düşünüyor ve böyle çalışıyor. Şu halde İstikbal bizimdir. Yarının doğacak güneşlerinin 1şı̆̆ 1 ve ümidi ile gözleriniz ve gözlerimiz gerçekten aydındir (Adiyaman Tam Bir, 1954, s.7).

Namık Gedik'ten sonra büyük tezahüratlar eşliğinde kürsüye gelen Meclis Başkanı Refik Koraltan Cumhurbaşkanı ve milletvekillerinin selamlarını ilettikten sonra sözlerine şöyle devam etmiştir:

Hakikaten fertlerin hayatlarında olduğu gibi cemiyetlerin hayatlarında da mesut, sayılı ve ebedî günler vardır. Büyük dâvaları benimseyen ve o büyük dâvaların uğrunda medeni insan olarak çalışan toplulukların eriştikleri zafer günleri ebedileşen günlerdir. Yine tarihin karanlık günlerinde bilhassa soyuna yakışan bir kahramanlık ve fedakârlıkla tehlikeleri önleyerek o karanlıkları yırtıp sabaha erişen ve kendi varlığını hem düşmanlarına, hem bütün bir dünyaya bir kere daha tanıtan milletler vardır. İşte aziz Adıyamanlılar siz Türkün şanlı tarihinde ebedileşen şerefli sayfaları ihraz etmiş, mâzinin derinliklerinde büyük işler görmüş, büyük millet çocuklarısınız. Yakın günlerde tarihimizin en kötü şartlar içinde tehlikeye ve uçuruma doğru yuvarlandığını o kara günlerde, içinde bulunduğumuz şartların ağırlığına bakmayarak istikbali gören ve ona gönül veren, koruyan, kurtaran ve kurtuluş yoluna götüren 
insanlarla birlikte olmasını, onlarla birlikte çalışmasını ve onlarla gönül birliği yapmasını bildiniz. Şimdi o samimi ve içten gelen emeklerinizin mükâfatını haklı olarak idrak etmiş bulunuyorsunuz. Duyduğunuz asil heyecan bundandır. Bu asil heyecanınıza katılmakla derin bir zevk ve bahtiyarlık içindeyiz. (Adıyaman Tam Bir, 1954, s.7).

Meclis Başkanı Urfa'dan özel olarak getirilen develerin kurban edilmesine müsaade etmemiştir. Şehir baştanbaşa bayraklar, yeşil dallarla süslenmiş, gece fener alayı tertip edilmiş ve şehrin meydanında halk oyunları oynanmıştır (Adıyaman ve Sakarya'da, 1954, s.7). Adıyaman'ın il olduğu gün yayımlanan nüshasında "torunlarımıza intikal edecek saadeti bizlere tattırmak lütfunda bulunan Hükümetimize, gönlümüze dolup taşan minnet duygular1mızı ifade edecek söz ve kelime bulmaktan aciz kalıyoruz" sözleriyle teşekkür eden Yeşil Adryaman gazetesi Adıyaman'ın il olmasında büyük emeği olan TBMM Başkanı Refik Koraltan'a şu sözlerle teşekkür etmiştir:

Bu kutsal günün yarattığı sevinci ifade etmek için tertiplenen şenlikler, yapılan tezahürat zahirinden mütalaa edilse bile erişilmeyecek büyüklüktedir. Hâlbuki temelleri gönüllerimizde gömülü olan bu şenlikler duyuşlarımızın ifadesi olmaktan aciz kalmaktadır. Zaten gönüllerdekini zuhur ettirmek beşerin Kudreti dışındadır. Saadetiyle kendimizi kaybedercesine sar hoş olduğumuz bu günde, farkına vardığımız bir şey varsa halde ve istikbaldeki mesut günleri başta B.M.M. Başkanımız Sayın Refik Koraltan'a borçlu olduğumuzdur, Çünkü bize bu vaadi o yapmış ve mevkiine yakışır şekilde de yerine getirmiştir. Ona bütün kalbimizle minnettarız. (Vilayetimiz Kuruluş Merasiminde, 1954, s.1,2)

CHP Adıyaman İl Başkanı Mahmut Deniz de "BMM Reisi pek Sayın Refik Koraltan'a açı teşekkür" başlı̆̆ ile yayımladığı teşekkür yazısında "İktidarınızın Adıyamana yaptığı tarihi büyük hizmetten, seçimler arifesinde Adıyamanı ziyaretiniz günü (seçimlerden sonra Adıyamanı ilk hamlede vilâyet yapacağız) vadinizi civanmertce ve gününde yerine getirdiğinizden, ayrıca Adıyamanımıza karşı beslediğiniz sevgi ve şefkatten dolayı bir Adıyamanlı ve CHP mensubu olarak BMM üyelerine bilhassa yüksek şahsiyetinize içimden doğan minnet ve şükranlarımı alenen arz ederim" demiştir (Vilayetimiz Kuruluş Merasiminde, 1954, s.1). Abdurrahman Kılıç tarafından kaleme alınan yazıda ise TBMM Başkanı Refik Koraltan ve İçişleri Bakanı Namık Gedik'ten hitaben "verdiğiniz sözün muhakkak yerine getirileceğini ispat etmiş olduğunuzdan cesaret alarak hakikati ne sırlı bir cam arkasından ve ne de Adıyamanımızı sizlere olduğundan daha güzel göstermek istemiyoruz. Durumu olduğu gibi arz etmenin daha doğru olacağı kanaatindeyiz. Vücuda 
getirdiğiniz binanın mefruşatını da tabii ki temin edeceksiniz. İşte bu mülahaza ile sizlerden birkaç istekte daha bulunuyoruz" (Kılıç, 1954, s.1-3) denilerek şu isteklerde bulunulmuştur; yol, Emlak Kredi Bankası'nın açlması, iskân suyu ve hükümet binası. Törenlerden sonra heyet Besni'ye gitmiş ve burada geniş bir halk kitlesi tarafindan karşılanmıştır. Halka hitap eden Meclis Başkanı Refik Koraltan Besni'nin bütün ihtiyaçlarının kısa zamanda halledileceğini ve özellikle yol yapılacağını dile getirmiştir (Koraltan Dün,1954, s.1).

\section{Adıyaman'ın İl Olmasından Sonraki Süreç}

Adıyaman il olduktan sonra ilk umumi meclis toplantısını 6 Aralık 1954'te yapmıştır. Vali İbrahim Kutlar burada yaptığı konuşmada "Hükümet bize büyük müzaheret vadediyor. Bizler de bu hususta elimizden geldiği kadar çalışacağız. Zira bu bizler için bir vatan ve millet borcudur... Ankara'ya gittikten sonra Almanya'ya gideceğim. Oradan biri şehircilik ve diğeri de istihsal mühendisi olmak üzere iki mühendis getireceğim. Bunlar yanımda müşavir olarak çalışacaklardır. Bunlardan büyük istifade göreceğimiz muhakkaktır" demiştir (Umumi Meclis Toplantısı, 1954, s.1).

Adıyaman il olduğunda Adıyamanlıların en çok sevindiği nokta kazalarının il olması ile şehrin ihmal edilmişliğinin sona ereceği ve şehrin gelişeceği ümidiydi. Bu yüzden Adıyaman'ın il olması Adıyamanlıları büyük bir sevince gark etmiştir. Bu sevinç doğal olarak büyük beklentileri de beraberinde getirmiştir. Bu beklentilerin ne düzeyde karşılandığı ise tartışmalıdır. Demokrat Adryaman gazetesi il olmasının dördüncü yılı için yayımladığı yazıda lise binasının ihalesinin yapıldığını, yol sorunun halledildiğini ve ilkokul binaları ile Ziraat Bankası'nın binasının yapıldığını belirtmiştir (Bugün Şehrimizin, 1958, s.1). Aynı gazete Adıyaman'ın il olmasının dokuzuncu yılı münasebetiyle yayımladığı yazıda "bugün on seneden beri vilayet olma mertebesine yükselen Adıyaman, hükümetin çeşitli imkânlarından faydalanmış büyümüş ve birçok alanlarda inkişaf etmiştir" demiştir (Bugün Şehrimizin, 1958, s.1). 1963 yılında ise Adıyaman genel durumu şöyleydi; Adıyaman 69 kilometrelik mükemmel bir şose ile demiryolu istasyonu bulunan Gölbaşı'na bağlanıyordu ve ilçelerinin hemen hepsine yol olmakla beraber bunların bir kısmı kışın kapanmaktaydı. Şehir merkezinde üç ilkokul, bir yatılı bölge kız ilkokulu, ortaokulunda içinde bulunan bir lisesi, bir akşam kız sanat okulu, bir pamuk mensucat fabrikası, 220 voltluk termo-elektrik santrali, modern bir devlet hastanesi ve bir trahom vardı. Ayrıca bazı devlet kurumlarının inşaatı devam etmekteydi (Çetin, 1963, s.2-6). 
Adıyaman'ın il olmasının on ikinci yılı vesilesiyle Demokrat Adryaman "Birçok imkânlar il teşkilatına dâhil olmak sebebiyle ayağımıza getirildi. Lise açıldı. Sağlık mevzunda ciddi tedbirler alındı. İş sahalarında yoksun ve fakru zaruret içinde bulunan Adıyamanımıza bir iplik ve dokuma fabrikasının inşasına başlandı. Yollar motörlü vasıtaların işleyebileceği şekle getirildi" demiştir (On İki Yıl, 1966, s.1). Demokrat Adıyaman'ın sorunların halledildiği görüşüne Adryaman gazetesi katılmamaktadır. Adıyaman'ın il olmasının üzerinden yirmi bir yıl sonra Adıyaman gazetesinde "Bir şehir 21 yllda ancak bu kadar ihmal edilir" başlığıyla yayımlanan yazıda çarpık kentleşme sonucu tamirhanelerin şehir içinde kaldığı, bunların çevre ve gürültü kirliği oluşturduğu, Adıyaman'ın temel sorunlarından biri olan yol sorunun devam ettiği yazmıştır (Bir Şehir, 1975, s.1).

\section{Sonuç}

Tarihinin farklı dönemlerinde birçok medeniyete ev sahipliği yapmış olan Adıyaman Cumhuriyetin ilk dönemlerinde Malatya'ya bağlı bir kaza idi. Adıyaman ile birlikte bugün Adıyaman sınırları içinde kalan Kâhta ve Besni'de Malatya'ya bağlı kazalardı. Coğrafi olarak Adıyaman ve Malatya Torosların devamı olan Malatya Dağları ile birbirinden ayrılır. Bu yüzden iki bölge arasında ulaşım oldukça zordur. Adıyamanlılar genelde Malatya'ya ulaşmak için genellikle Besni'ye bağlı Gölbaşı geliyorlar ve buradan Malatya'ya karayolu ve demiryolu ile ulaşıyorlardı. Bu durum iki yerleşim yerini birçok bakımdan birbirinden koparmaktaydı. Ayrıca bu durum Adıyamanlıların işlerini hayli zorlaştırmaktaydı. Bu yüzden Adıyamanlılar, şehirlerinin il olması yolundaki isteklerini her firsatta dile getirmiştir. Tek parti döneminde yeterince gelişmemiş yerlerden biri olan Adıyaman'ın çok partili hayata geçişten ve Demokrat Parti'nin iktidara gelmesinden sonra vilayet olması daha sıklıkla gündeme gelmiştir. Adıyamanlılar Demokrat Parti'nin dikkatini çekmek için kaza olarak 1950 seçimlerinde büyük oradan bu partiyi desteklemiştir. 1950 seçimlerinden sonra Adıyamanlıların il olmak için faaliyetlerini artırdıkları ve bu amaçla oluşturdukları heyetlerle sık sık Ankara'da temaslarda bulundukları görülmektedir. Nitekim bu temaslar sonuç vermiş ve Demokrat Parti yöneticilerinde Adıyaman'ın vilayet olması için söz almışlardir.

1954 seçimlerinde Demokrat Parti'nin Malatya'da hiç milletvekili çıkarmamış olması sebebiyle bazı araştırmacılar Demokrat Parti'nin Malatya'yı cezalandırmak ve Adıyaman'da aldığı oyların heba etmemek için Adıyaman'ı 
Malatya' dan ayırarak ayrı bir vilayet haline getirdiğini iddia etmiştir. Ancak DP'nin Adıyaman'ı il yapmasında bu durum kısmen etkili olmakla birlikte Adıyaman'ın il olmasının yegâne sebebi bu değildir. Adıyaman ve Malatya arasında coğrafi şartlar sebebiyle ulaşımın oldukça zor olması ve iki yerleşim yerinin Güneydoğu Torosları tarafından ayrılmış olması Adıyaman'ın il yapılmasındaki en önemli sebeplerden biridir. Ayrıca Adıyaman kazasının bulunduğu bölgenin yerleşime ve genişlemeye uygun olması da burasının tercih edilmesinde rol oynamıştır. Osmanlı döneminden itibaren geniş bahçelere sahip olan Adıyaman konumu itibarıla kurulan yeni vilayetin merkezinde yer alan bir yerleşim yeriydi (Moltke, 1969, s.206).

Adıyaman kazasının vilayet olmasından sonra geçiş sürecinde ihtiyaç duyulan kurumlar oluşturulmuştur. Oluşturulan resmi kurumlar dişında şehre gelecek memurların ihtiyaç duyduğu evlerin yapılması ve gereken önlemlerin alınmasıyla ilgili çeşitli çalışmalar da yapılmıştır. Adıyaman'da kurumların ihtiyaç duyduğu binalar yapılmış ve kazadaki teşkilatlar yeniden düzenlenerek vilayete geçiş için hazırlıklar yapılmıştır. Bu geçiş çalışmaları sırasında şehri tanıyan veya daha önce burada görev yapmış kişilere öncelik verilmiştir. Mesela Adıyaman Valiliğine daha önce Adıyaman kazasında kaymakamlık yapan İbrahim Tevfik Kutlar atanırken Develi Hâkimi Adıyamanlı Fuat Bilgin de Belediye Başkanı olarak seçilmiştir.

Adıyaman'ın il olması Adıyamanlılar için büyük sevinç kaynağı olmuştur. Adıyaman'ın il olduğunu günün kutsal gün olarak dönemin basınında yer alması Adıyamanlıların bu meseleye ne kadar önem verdiğini göstermektedir. Bazı Besnililer Adıyaman'ın vilayet olma sürecinde Gaziantep'e bağlanmak için çok çaba harcamasına rağmen Hükümet bu konudaki fikrini değiştirmeyerek Gaziantep'e Adıyaman'a göre iki kat uzaklıkta olan Besni'yi Adıyaman vilayetine bağlamıştır. Kazalarının il olmasıyla şehirlerinin her anlamda gelişeceğini ve resmi işlerinin daha da kolaylaşacağını düşünen Ad1yamanlılar bu değişime büyük umutla bakmışlardır. 


\title{
Extended Abstract
}

\section{Adryaman District Being a Province and Developments in this Process}

\author{
Mehmet Gündüz \\ İstanbul Boys High School \\ ORCID: 0000-0002-4642-4189
}

The administrative status of some settlements can be changed by administrative arrangements in Turkey. These administrative arrangements can be made for socio-economic or political reasons. Therefore, the transformation of districts into provinces brings some discussions. During the ruling Democratic Party, many administrative arrangements were made. While some districts were converted to province, Kırşehir province was converted into districts. One of the administrative arrangements is related to Adiyaman. The Democratic Party changed the status of Adiyaman district. Adiyaman district became a province in 1954. In this study, the process of becoming a province of Adiyaman district and developments in this process have been examined. In this process, debates in the Grand National Assembly of Turkey were discussed. In addition, public reactions to this process were examined. Within the scope of the study, the press of the period and other related studies were examined. In this concept of this study, the regulations made in this process and the expectations of the public were focused on Adiyaman's process of becoming a province.

Adiyaman came under rule of the Ottoman Empire and it was connected to Maraş province as a sanjak in 1519. Adiyaman was turned into a district under the Sanjak of Elbistan in 1531 and it was connected to Maraş again in 1563. Adiyaman was turned into a sanjak under the province of Diyarbekir with administrative arrangements after the Tanzimat in 1849. It was connected to the Sanjak of Malatya in 1859. Adıyaman was turned into a district of Malatya during the Republican period. Adiyaman had various administrative changes until it became a province. There were 6 sub-districts in Adiyaman in 1928. 
The Democratic Party dealt with the issue of Adiyaman being a province. Adiyaman residents made efforts to make their cities a province and for this purpose they met with a delegation they established in Ankara in 1953. On 19 February 1954, the Adiyaman Delegation held an hour-long meeting with Prime Minister Adnan Menderes and forwarded the requests of the Adiyaman people. The government took action to turn some districts into provinces in 1954. As a matter of fact, the Government decided to establish a new province in Adiyaman district of Malatya province. On 9 March 1954, the government submitted a bill to the Presidency of the Grand National Assembly of Turkey with the signature of Prime Minister Adnan Menderes. In legislative proposal, it was mentioned that Adiyaman did not fulfill the expected utilities. In addition, economic reasons are emphasized in the draft law. There were many institutions in Adiyaman that should be located in a province. There are socio-economic, geographical and political reasons for Adiyaman being a province. These reasons caused controversy between the power and opposition of the period.

When looked at the debates in Parliament, it is seen that all deputies, including Malatya deputies, supported Adiyaman to be a province. The connection of Besni to Adryaman is the most important issue in this process. Some deputies, especially Malatya and Gaziantep deputies argued that Besni should be connected to Gaziantep, not Adiyaman. Although Besni is closer to Adiyaman than Gaziantep, most of the speakers of Grand National Assembly of Turkey asked that this place to be connected to Gaziantep. The speakers especially pointed to the economic relations between Besni and Gaziantep. The speakers of Grand National Assembly of Turkey claimed that the people of Besni demanded that Besni must be connected to Gaziantep. The Government stated that there was no obstacle to the continuation of the economic relationship between Besni and Gaziantep. The Government stated that Besni is closer to Adiyaman. Therefore, it was suggested that Besni must be connected to Adiyaman.

It was predicted that Adiyaman province should be consist of Besni, Kahta and Gerger districts, in submitted draft law to the Grand National Assembly. However, during the draft law was being discussed in Parliament, a proposal was submitted from Çelikhan to Adıyaman and this proposal was accepted. 298 of 536 members of parliament participated in the voting of the draft law and entire members of parliament voted yes. However Malatya deputies did 
not attend the voting despite they were agree about being a province Adiyaman. On the other hand, five of the Gaziantep deputies attended and three of them did not to the as mentioned voting.

Some researchers claimed that being a province of Adiyaman was not a positive administrative legistation essentially, that was a kind of initiative to punish Malatya province. These researchers also stated that Besni is superior to Adiyaman in every aspect but Adiyaman is preferred as a province. According to researchers, the government did not choose this place because Besni supported the CHP in the general elections. However, it is difficult to express that as mentioned approach is completely correct because legislative proposal about being province of Adryaman was given almost two months before general elections in 2 March 1954. Furthermore, when Adiyaman was a province, the population of the city center was higher than Besni. Not only political reasons but also socio-economic and geographical conditions were effective about being a province Adryaman. Finally Adryaman became a province in 1954 and residents of Adiyaman were rather thankful and pleased about that circumstance. The local press attached extensive importance to that issue in its own period.

\section{Kaynakça/References}

Adapazarı ve Adıyaman Kazaları Vilayet Oldu. (1954, 15 Haziran). Milliyet, s.1-3.

Adıyaman Bucak mı Oluyor? (1953, 21 Eylül). Yeşil Adryaman, s.1.

Adıyaman Kazasını Bugünkü Durumu. (1954, 5 Haziran). Sabah, s.1.

Adıyaman Merasimle Vilayet Oluyor. (1954, 1 Aralık). Gayret, s.1.

Adıyaman ve Sakarya Dün Merasimle Vilayet Oldu. (1954, 2 Aralık). Gayret, s.1.

Adıyaman ve Sakarya'da Dün Büyük Törenler Yapıldı. (1954, 2 Aralık). Zafer, s.1,7.

Adıyaman Vilayet Oluyor. (1953, 3 Aralık). Yeşil Adıyaman, s.1.

Adıyaman Vilayeti. (1954, 24 Kasım). Gayret, s.1.

Adıyaman, Adapazarı Bugün Vilayet Oluyor. (1954, 1 Aralık). Zafer, s.7

Adıyaman, Tam Bir Bayram Havası Yaşadı. (1954, 3 Aralık). Zafer, s.1.

Adıyaman'ın Vilayet Olması Lazımdır. (1954, 22 Şubat). Yeşil Adıyaman, s.1.

Adıyaman'ın Vilayet Meselesi. (1954, 11 Ocak). Yeşil Adıyaman, s.2.

Adıyaman'ın Vilayet Olması. (1954, 16 Kasım). Gayret, s.1.

Adıyaman'ın Vilayet Teşkilatıın Çalışma Yerlerini Tespit İçin Gelen Heyet. (1954, 28 Ekim). Yeşil Adryaman, s.1.

Avaner, T. (2009). Prof. Dr. Hikmet Sami Türk ile röportaj: “Hukuk ve siyaset temelinde yerel seçimler: yerel seçim sistemi ve Mart 2009 seçimleri üzerine değerlendirmeler". Memleket Siyaset Yönetim Dergisi, 9, 33-54. 
Başbakan Menderes Heyeti Kabul Buyurdular. (1954, 21 Ocak) Yeşil Adıyaman, s.1. Başvekilin Dünkü Kabulü. (1954, 20 Şubat). Milliyet, 1954, s.7.

Besnililer Kazalarının Adıyaman'a Bağlanmasını İstemiyor. (1954, 7 Haziran). Sabah, s.1. Bir Şehir 21 Yılda Ancak Bu Kadar İhmal Edilir. (1975, 26 Mart). Adıyaman, s.1.

BMM Reisi Refik Koraltan. (1954, 28 Nisan). Sabah, s.1.

Bugün Şehrimizin Vilayet Oluşunun 4. Yıldönümü. (1958, 1 Aralık). Demokrat Adıyaman, s.1.

Çetin, Y. (1963, 21 Temmuz). "Adıyaman ili tarihi”. Yeşil Adıyaman, s. 2 ve 6.

Dâhiliye Vekâleti. (1928). Son Teşkilat-1 Mülkiye'de köylerimizin adları. İstanbul: Dahiliye Vekaleti Yayını.

Gene Aynı Dert. (1954, 4 Ekim). Yeşil Adıyaman, s.1.

Güzel Kazamızın Vilayet Olması. (1954, 31 Mayıs). Yeşil Adıyaman, s.1.

Hallaçoğlu, Y. (1988). Adıyaman. DİA, 1, 377-379

Hayallerden Hakikata. (1954, 15 Şubat). Yeşil Adıyaman, s.1,4.

İki Yeni Vilayet. (1954, 2 Aralık). Yeni Sabah, s.1

İşte Adıyaman (1971, 20 Mayıs). Çă̆daş, s.1.

Karabatak, N. (2017). 1950'li yıllarda Adıyaman, http://blog.milliyet.com.tr/1950-li-yillarda-adiyaman-/Blog/?BlogNo=576433

Kazamızın Vilayet Olmasından Kızan Besnililer. (1954, 7 Haziran). Yeşil Adıyaman, s.1.

Kılıç, A. (1954, 1 Aralık). Sayın Refik Koraltan ve Namık Gedik'den maruzatımız. Yeşil Adryaman, 1-3.

Kılıç, A. (1954, 18 Kasım). “Kutsal davamız”. Yeşil Adıyaman, 1.

Koraltan Dün Besnililere Hitap Etti. (1954, 3 Aralık). Sabah, s.1.

Moltke, H. (1969). Motlke'nin Türkiye mektupları. İstanbul: Remzi Yayınları.

On İki Yıl Evvel 1 Aralık Günü Adıyaman İl Oldu. (1966, 2 Aralık). Demokrat Adryaman, s.1.

Safi, İ., ve Kurşuncu, T. (2019). Siyasal partizanlığın bir göstergesi olarak seçim hileleri ve Türkiye'deki bazı uygulamaları. İktisadi İdari ve Siyasal Araştırmalar Dergisi, 4(8), 46-71.

T.C. Adıyaman Valiliği. (t.y.). Adıyaman tarihi. http://www.adiyaman.gov.tr/adiyaman-tarihi

T.C. Başbakanlık İGM (1961). 22 Ekim 1950 genel nüfus sayımı. İstanbul: İstatistik Genel Müdürlüğü Yayınları.

T.C. Başbakanlık IGGM (1961). 23 Ekim 1955 genel nüfus sayımı. İstanbul: İstatistik Genel Müdürlüğü Yayınları.

TBMM Millet Meclisi Albümü. (1970). Dönem III.

TBMMZC. (1954). Meclis tutanakları. TBMM Tutanak Dergisi. D.X, C.I.

TBMMZC. (1954). TBMM Tutanak Dergisi. Ek Kısmı. D.X, C.I.

TÜİK (t.y.). Seçim sonuçları. https://biruni.tuik.gov.tr/secimdagitimapp/secim.zul https://www.yenisafak.com/secim-1954/secim-sonuclari https://www.yenisafak.com/secim-1957/secim-sonuclari

Umumi Meclis Toplantısı. (1954, 13 Aralık) Yeşil Adıyaman, s.1. 
Vazife Bizi Bekliyor. (1954, 2 Eylül). Yeşil Adıyaman, s.1-2.

Vilayet Kuruluş Merasimi. (1954, 18 Kasım). Yeşil Adryaman, s.1.

Vilayet Oluşumuzun Dokuzuncu Senei Devriyesi. (1963, 1 Aralık). Yeşil Adryaman, s.1-6.

Vilayetimiz Kuruluş Merasiminde. (1954, 1 Aralık). Yeşil Adıyaman, s.1-2.

Yeni Belediye Reisimiz Geldi. (1954, 18 Kasım). Yeşil Adıyaman, s.1.

\section{Ekler}



Ek 1. Adıyaman ve Çevresinin Haritası 